\title{
Mental health in primary care: experience of matrix strategy in the rural area
}

\author{
Saúde mental na atenção básica: experiência de matriciamento na área rural \\ Salud mental en atención primaria: experiencia de estrategia matricial en el área rural
}

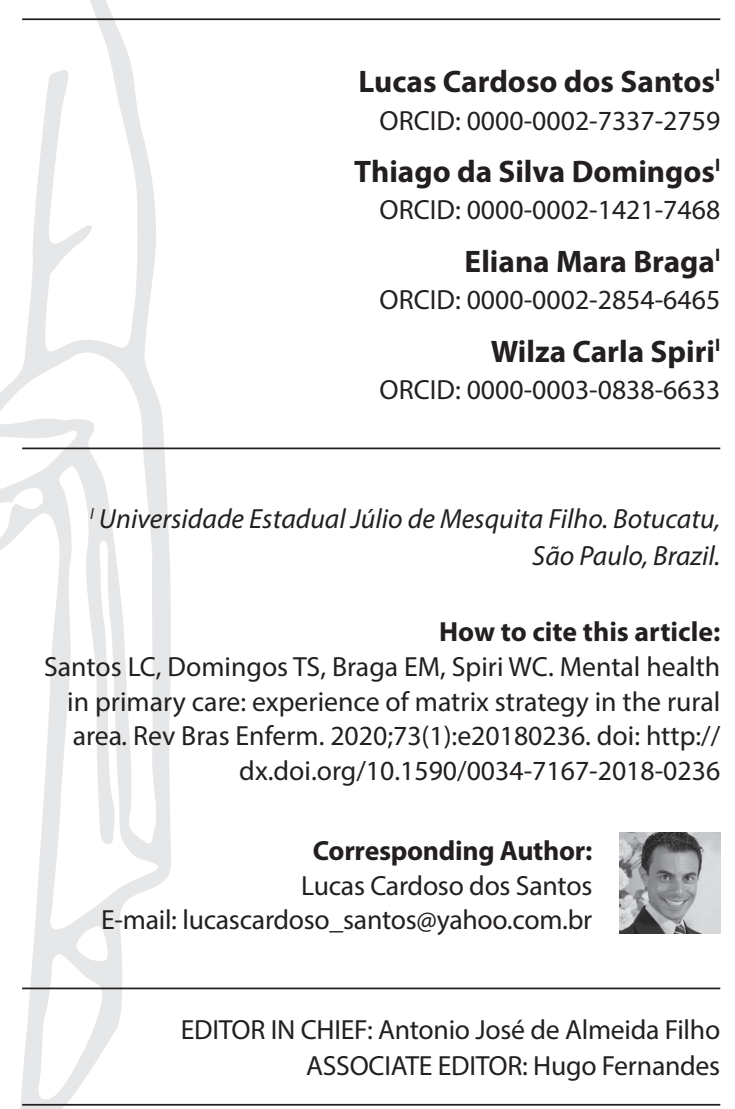

Submission: 04-19-2018

\begin{abstract}
Objective: to report the development of Mental Health actions shared between the Family Health Strategy located in a rural area and the Matrix Support Team by showing the communication resulting from this singular configuration. Method: report of experience about the implementation of actions of the Family Health Support Center (Portuguese acronym: NASF) in mental health care for a rural population. Results: the following health needs were identified: psychoactive drugs consumption, lack of activities for collective care and difficulty with access to service. The expansion of actions and intersectoral involvement of actors were demonstrated as the educational attitudes were implemented. Final considerations: the articulation between family health workers, matrix support and community was key for the implementation of mental health care aligned with the psychosocial approach.
\end{abstract}

Descriptors: Primary Health Care; Health Mental; Rural Health Services; Family Health; Interprofessional Relations.

\section{RESUMO}

Objetivo: relatar o desenvolvimento de ações de Saúde Mental compartilhadas entre a Estratégia Saúde da Família alocada em uma área rural e o Núcleo de Apoio Matricial, evidenciando as interlocuções decorrentes dessa configuração singular. Método: relato de experiência acerca da implantação das ações do Núcleo de Apoio à Saúde da Família no cuidado de saúde mental para uma população de área rural. Resultados: foram identificadas as necessidades de saúde: consumo de psicofármacos, escassez de atividades para o cuidado coletivo e dificuldade de acesso ao serviço. Conforme as atitudes educacionais foram implementadas, a ampliação das ações e o envolvimento dos atores com a intersetorialidade ficaram evidentes. Considerações Finais: a articulação entre os trabalhadores da saúde da família, do apoio matricial e da comunidade foi central para a efetivação do cuidado em saúde mental alinhado ao modo psicossocial.

Descritores: Atenção Primária à Saúde; Saúde Mental; Serviços de Saúde Rural; Saúde da Família; Relações Interprofissionais.

\section{RESUMEN}

Objetivo: relatar el desarrollo de acciones de Salud Mental compartidas entre la Estrategia Salud de la Familia ubicada en un área rural y el Núcleo de Apoyo Matricial, demostrando las comunicaciones derivadas de esa configuración singular. Método: relato de experiencia acerca de la implantación de las acciones del Núcleo de Apoyo a la Salud de la Familia en el cuidado de salud mental para una población de área rural. Resultados: se identificaron las necesidades de salud: consumo de psicofármacos, escasez de actividades para el cuidado colectivo y dificultad de acceso al servicio. La ampliación de las acciones y la participación de los actores con la intersectorialidad quedaron evidentes conforme las actitudes educativas fueron implementadas. Consideraciones finales: la articulación entre los trabajadores de la salud de la familia, del apoyo matricial y de la comunidad fue central para la efectividad del cuidado en salud mental alineado al modo psicosocial. Descriptores: Atención Primaria de Salud; Salud Mental; Servicios de Salud Rural; Salud de La Familia; Relaciones Interprofesionales. 


\section{INTRODUCTION}

The Brazilian Psychiatric Reform movement has brought several changes in the mental health care model. Ultimately, deinstitutionalization and psychosocial rehabilitation rescue the territory as a central element for health work in the horizon of psychosocial care ${ }^{(1)}$.

Primary Care is the central element in the articulation of the other institutions forming the Psychosocial Care Network (Portuguese acronym: RAPS). The interaction of Mental Health and Primary Care through the relationship of specialists and general practitioners promotes new interactions and professional practices, and develops new forms of public health care conducive to comprehensive care ${ }^{(1)}$. However, this integration poses as a challenge because of the following health care characteristics: actions focused on the biomedical model, verticalization of care and little valuation of the subject in care relationships ${ }^{(2)}$.

In order to broaden the scope and qualify the offer of Primary Care actions, the Ministry of Health has launched the Family Health Support Center (Portuguese acronym: NASF). It includes several professional categories working integrated with teams of Family Health Units (FHU) by incorporating concepts of matrix support and the reference team with the aim to transform the health work relationships ${ }^{(3)}$.

Specifically in mental health, the matrix support offered by NASF can enhance the approach and performance of diagnosis and therapy, strengthen the construction of unique and collective therapeutic projects, structure psychosocial interventions in basic care, and promote integration between specialized services. This scope of actions includes the construction of care offered to users in psychological distress. It is operationalized within the normative horizon of integrality, longitudinality, autonomy and emancipation of subjects in psychic suffering, besides the articulation of work services and processes, and of workers in the exercise of interprofessionality and collaborative work ${ }^{(4)}$.

\section{OBJECTIVE}

To report the development of Mental Health actions shared between the FHU in a rural area and the NASF by showing the communication resulting from this singular configuration.

\section{METHOD}

\section{Type of study}

Report of experience that contributes to discuss the strengthening of care aligned with psychosocial care and exercised in the knowledge and experiences in the primary care territory with its strengths and weaknesses.

\section{Study scenario}

This work was developed in a municipality located in the central western region of the state of São Paulo with a population of 132,566 thousand inhabitants, of which 34\% are covered by 11 Family Health Strategy units, and the rest is distributed in five Basic
Health Units and two School Health Centers ${ }^{(5)}$. The management of part of the Primary Care network is done by a Social Health Organization through a management contract with the City Hall.

The FHU studied was inaugurated in September 2003, but it previously functioned as a Basic Health Unit. It is located in the rural area of the municipality, about 25 kilometers far from the urban center with a coverage area equivalent to 10,000 hectares divided in four micro-regions and approximately 1,400 registered users.

The team consists of two nursing assistants, a nurse, a dental assistant, a dental surgeon, an administrative assistant, a general service assistant, four Community Health Agents (CHA), a physician and a pharmacy assistant. Apart from the dental surgeon, who has a workload of 20 hours a week, the other professionals are under the 40 weekly-hours regime.

With implementation of the NASF, the municipality was divided into five macro-regions by demographic similarities and geographic proximity. Professionals of the Matrix Support Team were assigned for each macro-region, and they worked in Health Units in a specific day of the week in order to perform the matrix support.

The health professionals integrated into Primary Care (Basic Units and Family Health Units), two physical educators, five pharmacists, two physiotherapists, a social worker, a psychologist and two nutritionists were divided into two teams that are distributed among the units every two weeks and organized in the form of trios (psychologist, social worker, physiotherapist) or pairs (physical educator and nutritionist). Medical professionals (gynecologist and psychiatrist) are also part of this team, but unlike the previous professionals, they are distributed monthly between units.

\section{Data source}

With the beginning of NASF activities in the Health Unit, the work process changes resulting from the matrix support were discussed in several meetings, which demonstrated the demands and critical nodes. In team meetings with participation of all workers, were identified weaknesses such as care for patients using psychoactive drugs, lack of actions in group logic and collective care, and access to the unit by considering the extent of territory.

Regarding the first problematic, since the stock of psychotropic drugs remained centralized in the municipality's warehouse, for medicine dispensing, users should visit the Health Unit twice a month in the interval of one week: one to renew the prescription and another to withdraw the medication, which would then be dispensed for a two-month period. As a result of this operation, failures in providing prescriptions in a timely manner and delayed release or transportation of medication affected users, who would need to visit the service for a third time.

Another negative consequence of this process was the indiscriminate continuity of medication use. Drugs were prescribed without users' follow-up, in spite of control efforts in the Health Unit by dispensing medication through information (medication delivered, quantity, date and signature of the person responsible for dispensation) contained in a book. The medication dispensing for the two-month period raises issues regarding the safe use of psychotropic drugs and possible inherent risks. 
As for collective care actions, in the Health Unit, there was only the quit smoking group with weekly meetings held by the mental health team and participation of the unit's physician for prescribing nicotine patches or other medications needed.

\section{Collection and organization of data}

Based on these fragile points of the work process, the FHU and NASF teams planned to redirect and reorganize the actions of each employee of the unit teams through the exercise of joint responsibility for the care of mental health users.

During meetings, there were actions to raise awareness about the use of psychoactive drugs and health care among workers. This arouse the proposal of a survey in the covered area of users in use of psychotropic drugs, medications consumed and the possible problems experienced that triggered psychic suffering. In this step, were used patients' medical records and workers' knowledge about the population.

\section{Work steps}

Sixty-six patients were identified, of whom 42 women and 24 men, few years of schooling, occupations in domestic chores and maintenance of small farms with agricultural and livestock tasks. Among the reasons that led to consumption of psychoactive drugs, were aspects of health care medicalization, since many users started using because of family problems (often of marital order), given the peculiar routine of the rural setting with few leisure opportunities and scarcity of resources for that purpose in the scope of the FHU, and by the distance from the urban center.

Health Education activities were an intervention strategy planned in the logic of open group meetings held weekly in the physical space of the health unit at a previously established time and date, and duration of approximately one hour. For publicity, leaflets were delivered by community health agents during home visits, posters were placed in the Health Unit and social spaces in the area, and invitations were made during consultations or other visits. When meetings started to happen, sessions themselves were vehicles for spreading the strategy as users commented with each other about the intervention proposal.

At the beginning of each meeting, were presented the objectives and rules (confidentiality and reliability, mutual respect and use of cell phones). At the end, users were informed of the time and date of the next meeting.

The number of users fluctuated between ten and 25, mostly women with turnover of people at each meeting, thus, new participants joined and others left the group. These characteristics enriched the meetings by bringing the diversity of experiences shared and reflected from the point of view of different subjects and their conceptions. Another aspect related to the characterization of subjects was their low educational level, which demanded professionals' attention regarding the language adopted by always seeking to facilitate the understanding of all.

At the meetings, the intention was to address topics of interest for participants, among which: the reasons that led the Health Unit to rethink the psychotropic drug dispensing and possible changes in the acquisition of medicines; definition and function of psychotropic drugs; difference between anxiolytics and antidepressants; storage of medicines; importance of correct use; integrative and complementary practices; quality of sleep; physical activity and leisure; phytotherapeutic medications; use of teas and pharmacological dependence. The resources used to approach the topics included: conversation circles, relaxation and stretching practices, tea preparation workshop, circle dance, aerobic activities, illustrative videos and interpersonal dynamics.

The facilitation process was through rotation between workers of the Family Health Strategy and the NASF team for group coordination in pairs by addressing themes aligned with their training area and skills. The only workers present at all meetings were the nurse, pharmacist and CHAs.

Participation of CHAs was key for the groups, as these professionals contributed to recognize and identify situations with potential to become health problems. Furthermore, the bond between $\mathrm{CHAs}$ and the community promoted adherence to activities proposed by the Health Unit, facilitated the team's approach in order to focus on themes that users would like to address, and signaled about the community impressions of the groups.

The implementation of NASF brought changes to pharmacists and pharmacy assistants included in the FHU teams. The presence of pharmacists in the units began on specific days for dispensing psychoactive drugs included in the inventory of pharmacies in the FHU. These professionals began to develop clinical management in pharmaceutical care that, in addition to collaborative work, provided rational use of medicines, control and inventory, and improved patient care.

In general, in their first participation in the group, users felt ignorant and difficulty with sharing experiences or clarifying doubts, but with time, the attitude of estrangement was replaced by more active participation, which demonstrated a greater understanding of the work proposal.

After some meetings, was implemented the new form of psychoactive drug dispensing, despite users' resistance verbalized by the fear of not acquiring medication if they did not request a new prescription at the Health Unit. After operationalization of this process, when medication was ending, users would no longer need to request a new prescription, since this control became the team's responsibility.

Therefore, medications were dispensed at the end of group meetings and in the amount according to the interval between meetings. Psychotropic drug dispensing was not subordinated to participation, although users were always encouraged to attend. The Health Unit team resumed group or individual follow-up through medical or nursing consultations as a requirement for access to medication. This process promoted quality of care to the population user of psychoactive drugs.

Another change was in the quantity dispensed, since the interval between meetings was considered. If the patient visited the unit before the proposed day, or if the medication ended before the established deadline, the Health Unit became aware and triggered an approach to the user for understanding the problem.

The approach to users of psychoactive drugs enabled a qualified monitoring and a change in the relationship between the user and the medication. In this process, some decided to stop taking the psychoactive drug, for whom the Health Unit team proposed the process of weaning or gradual withdrawal. 
With discussions taking place in the groups, users and workers of the Health Unit and NASF agreed on the need to develop more activities in the same line with other approaches. This started the Craft Workshops, where users taught others how to paint cloths; group for users with chronic pain, where physical educator and physiotherapist applied the matrix strategy to the Health Unit workers, and from this action arose the Walking and Aerobics groups.

After development of these last two groups and support of the Nutritionist of the Matrix Support Team, began the Culinary Workshops. Health Unit workers and users developed easy and low-cost recipes together, and had tastings at the end of aerobic or walking activities. Another partnership was signed with the Reference Center for Social Assistance (Portuguese acronym: CRAS), and from it, were held Workshops of Embroidery in Slippers and Preparation of Fruit Preserves.

In the initial months of implementation of the new approach to users of psychoactive drugs, part of them stopped attending the service. When asked about the reason, they reported still having medicine in stock. As months went by, increased the visits to the Health Unit for receiving medication thereby approaching the originally planned control. This situation reinforces aspects of safety and rational use of psychoactive drugs, besides demonstrating the effectiveness of the measure organized in the FHU by the health team together with the Support Team.

In the context of this experience, the difficulty with access to service and residences is a challenge for users and workers in the rural area, and sometimes a motive preventing participation in activities developed in the Health Unit. Even with planning, the actions did not meet some particularities, which led some users to keep the medication withdrawal at times and days when they could arrange rides to the Health Unit or when CHAs took medicines during home visits.

The difficult access resulted in a greater concentration of participants in the groups (around 25 users) and consequent quality of exchange among users. This situation demonstrates the importance of considering the particularities of territories in rural areas in health actions for meeting the principle of equity and access.

\section{DISCUSSION}

Matrix Support is a strategy in the work process of the Family Health Strategy that favors longitudinality of care, strengthens user embracement, bonding and joint responsibility, which in turn, increases the resolution of mental health demands and the promotion of devices in the logic of Psychosocial Care. As a consequence, there are reflections on the insertion of people with mental disorders in the community, which strengthens spaces for exchanging experiences between the actors involved (community, family and users, social equipment, managers, health professionals and related areas) and actions of continuing education in health around the issue ${ }^{(6)}$.

Given the generalist training, primary care workers need spaces that promote the development of competencies, skills and attitudes in order to provide basic care, identify psychological suffering and complex cases, and share the care with specialized services. At another point, Matrix Support professionals need to be prepared for a collaborative and interprofessional practice by providing supervision and support ${ }^{(7)}$.
By working together, professionals can share responsibilities, feel more secure, strengthen themselves for dealing effectively with the work process, and realize they are not alone in solving cases $^{(4)}$. The collective construction of knowledge and care in practice has been a power of the Matrix Support action in the Family Health Strategy ${ }^{(8)}$ aligned with the reported experience. It enabled the development of care and technical-pedagogical dimensions that are conceptual aspects of the matrix strategy.

In this report, in addition to geography, the territory organizes a multiplicity based on the intersection between Psychosocial Care and Primary Care in a way that requires thinking of care in terms of its time and space. As a consequence, expanding the care strategy involved various parts of the Psychosocial Care Network, different subjects, the exercise of sociability, subjectivity and a bet on the "various forms of making life move"(1).

In the unit located in the rural area, psychic suffering has other causes and repercussions, and knowledge about them bases the different actions developed by health services. Knowledge of community, the social language and customs makes mental health care more effective, establishes therapeutic alliances and strengthens the bonding of users with health workers ${ }^{(4)}$.

Another important aspect is the understanding of medical consultations as a central tool for solving mental health demands, where users, their relatives and health professionals see the care of physicians as the only main path. Hence the tendency to value not only the medical professional, but also medicalization, which proves to be ineffective when dissociated from psychosocial interventions ${ }^{(9-10)}$. Other health workers are also secondarily placed in care, thereby leading to compartmentalization and disconnection from care ${ }^{(1)}$. However, the activities reported facilitated users' contact with other professional categories within the health team through the Matrix Support, which offered another experience of clinical and care management - from that based on the individualized biomedical hegemony to the extended clinic and of the subject.

\section{Limitations of the study}

The limitations of this report are related to the small number of participants between workers and health service users. The specificity of the scenario where the narrated experience unfolded also made it difficult to discuss the strengths and weaknesses with other experiences.

\section{Contributions to health}

The dialogues discussed in this experience can instrumentalize and potentiate other care practices focused on the articulation of services guided by matrix, territorial and psychosocial logic. The accumulation of experiences also favors the expansion and strengthening of these practices as tools in Primary Care to subjects in psychic suffering and advances in little explored interfaces in the academic, care and political environments.

\section{FINAL CONSIDERATIONS}

The matrix support was fundamental to perform the activities, because it provided a constant dialogue among professionals, which resulted in an integral and resolutive work process. 
The various professional categories involved enriched the discussions and approaches in group and aroused the curiosity and interest of users and workers of the Health Unit and the Support Team about care issues. At first, in the scope of mental health, then gradually expanding for the development of strategies and inclusion of social equipment. All activities were only possible with teamwork and by the need to perform other activities in groups, as pointed by users themselves, and with the expanded look to other dimensions related to mental health.

The approximation between the Family Health Strategy, NASF and the community facilitated adherence to the proposed activities, which was also driven by the reunion of subjects sharing something in common: users in psychic suffering having their health needs met in an expanded way, and professionals focused on improving the quality of care provided to patients using these medications.

The experience showed that the association of health education and matrix support offered by NASF enabled the systematization of medication dispensing in the FHU, increased the creation of actions in the logic of collective care through groups with different approaches, and also favored the integrality and longitudinality of care under the logic of collaborative and interprofessional practice.

\section{REFERENCES}

1. Yasuí S, Luzio CA, Amarante P. Atenção psicossocial e atenção básica: a vida como ela é no território. Rev Polis Psique. 2018;8(1):173-90. doi: $10.22456 / 2238-152 X .80426$

2. Moliner J, Lopes SMB. Saúde mental na atenção básica: possibilidades para uma prática voltada para a ampliação e integralidade da saúde mental. Saude Soc. 2013;22(4):1072-83. doi: 10.1590/S0104-12902013000400010

3. Ministério da Saúde (BR). Secretaria de Atenção à Saúde. Departamento de Atenção Básica. Núcleo de Apoio à Saúde da Família - Volume 1: Ferramentas para a gestão e para o trabalho cotidiano (Cadernos de Atenção Básica, n 39) [Internet]. Brasília: Ministério da Saúde; 2014 [cited 2018 Mar 25]. Available from: http://bvsms.saude.gov.br/bvs/publicacoes/nucleo_apoio_saude_familia_cab39.pdf

4. Gonçalves DA, Ballester D, Chiaverini DH, Tófoli LF, Chazan LF, Almeida N, et al. Guia prático de matriciamento em saúde mental [Internet]. Brasília: Ministério da Saúde; 2011 [cited 2018 Mar 25]. Available from: http://bvsms.saude.gov.br/bvs/publicacoes/guia_pratico_ matriciamento_saudemental.pdf

5. Carandina L, Almeida MAS. Botucatu em dados. Botucatu: Universidade Estadual Paulista "Júlio de Mesquita Filho", Faculdade de Medicina de Botucatu; 2005.

6. Azevedo DM, Gondim MCSM, Silva DS. Apoio matricial em saúde mental: percepção de profissionais no território. Rev Pesqui Cuid Fundam Online. 2013;5(1):3311-22. doi: 10.9789/2175-5361.2013v5n1p3311

7. Jorge MSB, Vasconcelos MGF, Castro Junior EF, Barreto LA, Rosa LRS, Lima LL. Solvability of mental health care in the Family Health Strategy: social representation of professionals and users. Rev Esc Enferm USP. 2014;48(6):1059-65. doi: 10.1590/S0080-623420140000700014

8. Moura RFS, Silva CRC. Saúde mental na atenção básica: sentidos atribuídos pelos agentes comunitários de saúde. Psicol Cienc Prof. 2015;35(1):199-210. doi: 10.1590/1982-3703001832013

9. Pinto AGA, Jorge MSB, Vasconcelos MGF, Sampaio JJC, Lima GP, Bastos VC, et al. Apoio matricial como dispositivo do cuidado em saúde mental na atenção primária: olhares múltiplos e dispositivos para resolubilidade. Cienc Saude Colet. 2012;17(3):653-60. doi: 10.1590/ S1413-81232012000300011

10. Costa FRM, Lima VV, Silva RF, Fioroni LN. Challenges of matrix support as educational practice: mental health in primary healthcare. Interface (Botucatu). 2015;19(54):491-502. doi: 10.1590/1807-57622013.0816 